\title{
The expansion of agribusiness in ceará semiarid region and their implications for health
}

\begin{abstract}
Since 2008, Brazil is the worldwide leader in pesticide's consumption. In the other hand, looking through a public health point of view, the rates of intoxication by pesticides are rising - they reached 9.000 notifications only in the year of 2012.The present article aims to analyze its implications in health due the insertion/expansion of agribusiness in Ceará semiarid. There are several implications for the health of rural workers and the rural population. Epidemiological study with rural workers in the city of Limoeiro do Norte, Ceará, Northeast Brazil, showed chromosomal changes in bone marrow cells among the participants. Of 35 viable samples, 11 presented chromosomal alterations as deletions of chromosomes 5, 7 and 11; Monosomy of TP53 and amplification of TP53. These data contribute to evidence that the chemical-dependent model of agrochemicals adopted in Brazil promotes serious public health problems.
\end{abstract}

Keywords: environmental exposure, pesticides, organophosphate poisoning, occupational exposure, occupational risks
Volume 3 Issue 4 - 2017

\author{
Marcelo Jose Monteiro Ferreira \\ Departamento de Saude Comunitaria, Universidade Federal do \\ Ceara, Brazil
}

\begin{abstract}
Correspondence: Marcelo Jose Monteiro Ferreira, Departamento de Saude Comunitaria, Faculdade de Medicina, Universidade Federal do Ceará (UFC), R. Professor Costa Mendes 1608/Bloco Didático/5 Andar, Rodolfo Teófilo: 60430 I40 Fortaleza Ceará Brasil, Email marceloferreira@ufc.br
\end{abstract}

Received: August 05, 2017 | Published: August 15, 2017

\section{Introduction}

Since 2008, Brazil has been ranked the world's leading importer of pesticides in the world, accounting for $86 \%$ of total consumption in Latin America. ${ }^{1}$ In 2010 alone, the countries sales growth rate was $190 \%$, while in the rest of the world it was $93 \% .^{2}$ However, the above figures neglected the consequences of the deleterious effects of pesticides on human health and ecological balance. From the point of view of public health, we identified an increase in pesticide intoxication rates registered by the Notification of Injury Information System (SINAN), which, in 2012 alone, reported more than 9.000 cases. ${ }^{3}$ According to the World Health Organization (WHO), for each confirmed case, an additional 50 underreported individuals are estimated, which would lead us to a quantitative of approximately 450.000 cases, thus representing a serious public health problem. In addition, there are also accidents at work due to poisoning by pesticides, which in 2011 were $126.77 \%$ more than in $2007 .{ }^{4}$ Another worrying aspect concerns the age group of intoxications, mainly affecting males aged $20-34$ years. 5

\section{Case presentation}

An epidemiological study carried out in three municipalities located in Ceará, Northeast Brazil, showed an annual increase in hospitalization rates due to neoplasm's 1.76 times higher when compared to other eleven municipalities. The analysis showed that the cancer mortality rate is $38 \%$ higher in the three municipalities mentioned above, demonstrating the influence of the productive processes on the disease and death profile of the populations. ${ }^{6}$ Concerning health concerns, a survey carried out during the period 2007 to 2011 in the semi-arid state of Ceará revealed, among others, that $97 \%$ of agribusiness workers and the family farmers studied were exposed to agrochemicals. Such exposure involved the presence of 4 to 30 different active ingredients, distributed among insecticides, herbicides and fungicides. In the set of data, it was possible to identify the presence of 25 different chemical groups, of which $68.5 \%$ are classified as extremely toxic or very toxic. ${ }^{7}$ Epidemiological study conducted in three municipalities in Ceará, Northeast Brazil, involved 545 rural workers using clinical exams and laboratory tests. Of these, $46.6 \%$ related some health problems to pesticides and $43.3 \%$ referred to signs and symptoms compatible with acute intoxications in their previous history. The number of workers who at the time of the examination presented similar symptoms to acute intoxication by pesticides was high enough. ${ }^{8}$ Regarding hepatic function, all of the nine laboratory indicators used for evaluation showed some variation, suggesting hepatocytes hypertrophy and necrosis, cholestasis and bile duct damage. Oxalacetic transaminase increased by $6.2 \%$, pyruvic transaminase in $14 \%$ of cases and alkaline phosphatase by $6.2 \%$. It is noteworthy that these three indicators are used by the Pan American Health Organization (PAHO) to correlate chronic hepatic lesions with exposure to pesticides. ${ }^{8}$ Another study, carried out in Limoeiro do Norte with rural banana producers, concluded that chronic exposure to pesticides led to the occurrence of chromosomal changes in bone marrow cells of 35 viable samples, 11 presented important chromosomal alterations, being: deletions of chromosomes 5, 7 and 11; Monosomy of TP53 and the amplification of TP53. The abnormalities found are similar to changes described in clonal diseases of the bone marrow, such as myelodysplastic syndromes and acute myeloid leukemias. ${ }^{9}$ All these data interact with the context experienced by several communities in the semi-arid region of Ceará. A cross-sectional study, based on secondary data records, calculated the Proportional of Cancer Ratio Incidence (PCIR) in the main anatomical sites of cancer in the state of Ceará. The results showed a higher risk of cancer in farmers in the region when compared to nonfarmers in fifteen of the twenty-three studied locations, the greatest differences being for penile cancer (6.44), leukemias (6.35) and testicles (5.77). ${ }^{10}$

\section{Final considerations}

The growing expansion of agribusiness in Brazil can be measured by the magnitude of its revenues, especially in the last ten years. Each year, this "model" of chemical-dependent production expands its borders to various regions of the country. The indiscriminate use 
of agrochemicals promotes serious changes in health, especially in rural workers and populations living in the vicinity of agribusiness monoculture companies. This context proves to be a serious concern for public health in the country.

\section{Acknowledgements}

None.

\section{Conflict of interest}

The author declares no conflict of interest.

\section{References}

1. Sindag. Sindicato Nacional das Indústrias de Defensivos Agrícolas. Brazil: Dados de produção e consumo de agrotóxicos; 2010.

2. Pelaez V. Monitoramento do Mercado de Agrotóxicos. Brasília: Agência Nacional de Vigilancia Sanitária; 2012.

3. Ministério da Saúde. DATASUS. Brazil: Sistema de Informação de Agravos de Notificação; 2012

4. Ministério da Saúde. DATASUS. Brazil: Sistema de Informação de Agravos de Notificação; 2012.
5. Ministério da Saúde. DATASUS. Brazil: Sistema de Informação de Agravos de Notificação; 2013.

6. Rigotto RM, Silva AMC, Ferreira MJM, et al. Tendências de agravos crônicos à saúde associados a agrotóxicos em região de fruticultura no Ceará, Brasil. Ver BrasEpidemiol. 2013;16(3):763-73.

7. Rigotto RM. Agrotóxicos, trabalho e saúde: vulnerabilidade e resistencia no contexto da modernização agrícola no baixo Jaguaribe/ CE. 1st ed. Brazil: Edições UFC; 2011.

8. Rosa IF, Pessoa VM, Rigotto RM. Introdução:agrotóxicos, saúde humana e os caminhos do estudo epidemiológico. In: Rigotto RM (Organizador). Agrotóxicos, trabalho e saúde: vulnerabilidade e resistência no contexto da modernização agrícola no Baixo Jaguaribel $C E$. Fortaleza/São Paulo: Edições UFC-Expressão Popular; 2011. p.217-56.

9. Ferreira Filho LIP. Estudo das alterações citogenômicas na medula óssea de trabalhadores rurais expostos à agrotóxicos. Fortaleza (Ceará): Universidade Federal do Ceará; 2013.

10. Ellery AEL, Arregi MMU, Rigotto RM. Incidência de cancer em agricultores em hospital de câncer no Ceará. In: XVIII IEA World Congresso ofEpidemiology, VII Congresso Brasileiro de Epidemiologia, Brazil; 2008. 